\title{
Separate and combined impacts of land cover and climate changes on hydrological responses of Dhidhessa River basin, Ethiopia
}

\author{
Gizachew Kabite Wedajo $^{\text {a,b*}}$, Misgana Kebede Muleta ${ }^{c}$, Berhan Gessesse Awoke ${ }^{b, d}$

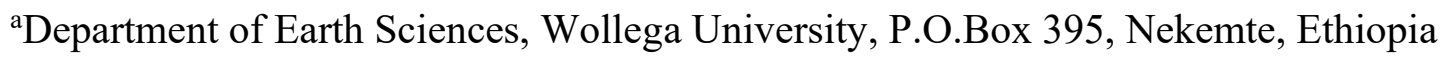 \\ Kabiteg@gmail.com
}

bepartment of Remote Sensing, Entoto Observatory Research Center, Ethiopia Space Science Technology Institute, P.O.Box 33679, Addis Ababa, Ethiopia

berhanavu@gmail.com

${ }^{\mathrm{c}}$ Department of Civil and Environmental Engineering, California Polytechnic State University, San Luis Obispo, California, 93407

mmuleta@calpoly.edu

${ }^{\mathrm{d} D e p a r t m e n t ~ o f ~ G e o g r a p h y ~ a n d ~ E n v i r o n m e n t a l ~ S t u d i e s, ~ K o t e b e ~ M e t r o p o l i t a n ~ U n i v e r s i t y, ~ A d d i s ~}$ Ababa, Ethiopia

*Correspondence: Email: Kabiteg@gmail.com; Mobile: $+\underline{251911951952}$ 


\begin{abstract}
Land cover and climate changes greatly influence hydrologic responses of a basin. However, the response vary from basin to basin depending on the nature and severity of the changes and basin characteristics. Moreover, the combined impacts of the changes affect hydrologic responses of a basin in an offsetting or synergistic manner. This study quantified the separate and combined impacts, and the relative contributions of land cover and climate changes on multiple hydrological regimes (i.e., surface runoff, streamflow, groundwater recharge evapotranspiration) for the Dhidhessa Subbasin. Land cover and climate change data were obtained from a recent study completed for the basin. Calibrated Soil and Water Analysis Tool (SWAT) was used to quantify the impacts. The result showed that SWAT model performed well for the Dhidhessa Subbasin in predicting the water balance components. Substantial land cover change as well as an increasing temperature and rainfall trends were reported in the river basin during the past three decades. In response to these changes, surface runoff, streamflow and actual evapotranspiration (AET) increased while groundwater recharge declined. Surface runoff was more sensitive to land cover than to climate changes whereas streamflow and AET were more sensitive to climate change than to land cover change. The combined impacts played offsetting effect on groundwater recharge and AET while inconsistent effects within study periods for other hydrologic responses. Overall, the predicted hydrologic responses will have negative impacts on agricultural production and water resources availability. Therefore, the implementation of integrated watershed management strategies such as soil and water conservation and afforestation could reverse the negative impacts.
\end{abstract}

Keywords: Hydrological responses; global environmental changes; Dhidhessa Subbasin; Land cover change; Climate change; Combined impacts. 


\section{Introduction}

Land cover and climate changes are key components of global environmental changes $[1,2,3,4]$. Human-induced land cover change affects the biophysics, biogeochemistry and biogeography of the terrestrial surface and the atmosphere [5,6]. These changes in material and energy cycle of the Earth's systems affect energy balance between land surface and atmosphere subsequently resulting in climate and ecosystem changes $[6,7,8,9]$. Overall, land cover change together with climate forcing influences the atmosphere and land surface processes $[9,10]$.

Land cover change affects hydrological processes by altering evapotranspiration (ET), soil water holding capacity of a soil, infiltration, precipitation interception capacity $[10,11,12]$ and runoff travel times [12]. Consequently, land cover change modifies the quantity and quality of surface and subsurface water flows $[3,13]$, the magnitude and frequency of floods and droughts [14], and regional and global climate systems. At basin scale, the effect of land cover changes on hydrological processes are reflected in the supply-and-demand balance of water resources, which in turn affect ecosystems, environment and economy [1]. Generally, the separate and the combined impacts of land cover and climate changes influence the environment particularly hydrological processes of a basin.

Therefore, investigating the impacts of land cover and climate changes on hydrological processes became a major research topic during the last few decades. Studies demonstrated that land cover and climate changes greatly affect hydrologic responses of a basin $[15,16,17]$. The magnitude of the change, however, varies from basin to basin depending on the basin characteristics such as geography, geology, topography, climate conditions, and intensity of land cover changes. Hydrological responses to land cover and climate changes could exhibit spatiotemporal variability even within a basin $[16,18]$. Moreover, the relative contribution of land cover and climate changes varies from region to region.

As a result, research findings on the topic remain inconclusive. For example, some studies reported that climate change influences hydrologic response more than land cover change $[4,15,19]$; others claimed that hydrologic responses are more sensitive to land cover change than to climate change $[20,21,22]$. On the other hand, some studies argued that it is vital to consider 
impacts of both land cover and climate changes on hydrologic responses than examining the separate impacts $[19,23]$. The combined impacts could have either synergistic or offsetting effects compared to the impact resulting from neither factor [15,19]. For example, Shrestha and Htut [19] reported that the combined impacts of land cover and climate changes on streamflow is more significant than their separate impacts in Mynamar. Zhang et al.[4], however, reported that hydrological response to the combined effect is similar to those induced by climate change alone in China. These studies showed that impacts of climate and land cover changes on hydrological responses can't be generalized as they could be basin specific. Therefore, considering the separate and combined impacts of land cover and climate changes on hydrologic responses is essential to understand the hydrological processes and design effective water resource management strategies $[24,25]$.

Despite this acknowledgement, only limited studies [15,26,27] have investigated the impacts of both land cover and climate changes on hydrological responses. According to Krysanova and White [28], for example, only 30 peer-reviewed papers published between 2004 and 2015 addressed the combined effects of land cover change and climate change at global scale using SWAT model. In comparison, 210 and 109 peer-reviewed papers were published considering the separate impacts of climate change and land cover change, respectively between 2004 and 2015. However, papers published on the combined impacts of land cover and climate changes have been increasing recently but still more papers are dealing with the separate than the combined impacts. In addition, studies showed the need to investigate the impacts of the changes on hydrologic responses at local scale $[29,30]$. This is because the effect can be evident at subbasin scale than at basin scale [4,31]. In addition, most of the existing studies examined one or limited number of hydrologic responses (e.g., surface runoff, streamflow, evapotranspiration or groundwater recharge) to analyze the impacts $[8,12,17,29,32,33,34]$.

The separate and combined impacts of land cover and climate changes on hydrological processes can be investigated using process based hydrological model [32,35]. Hydrological model (e.g., Soil and Water Assessment Tool; SWAT) is best options for integrated modeling approach because of their capability to predict hydrologic responses to spatiotemporally variable inputs (e.g., land cover and precipitation). These inputs can be derived from satellite remote sensing, or field (ground) data. Remote sensing is more viable for data-scarce basins due to its cost- and time- 
effectiveness, large area coverage, consistent data quality, and provision of long-term spatiotemporal global information [36,37,38]. However, remote sensing data have unavoidable errors emanated from different sources of errors, therefore, should be calibrated and validated before use before using it for any applications.

The Dhidhessa River basin has experienced substantial land cover and climate changes during the last three decades $[39,40]$. However, the hydrologic responses to these changes as well as the relative contribution of land cover and climate changes on hydrologic responses are not investigated in most basins of Ethiopia including for the Dhidhessa Subbasin. In this study, we examined both the separate and the combined effects of land cover and climate changes on hydrological responses at regional (local) scale for Dhidhessa River basin. We used an integrated modeling approach to quantify the impacts on multiple hydrological processes including surface runoff, streamflow (water yield), groundwater recharge and evapotranspiration using satellite rainfall product. The Dhidhessa River basin has experienced substantial land cover and climate changes during the last three decades [39,40]. This study analyzed the effects of these changes on multiple hydrological responses of the basin that contributes more than $25 \%$ of Blue Nile River's streamflow during dry season. Results of this study can be valuable to manage existing and planned water resources projects in Didhessa River basin, Blue Nile basin, and other hydrologically similar basins in Ethiopia and elsewhere.

\section{Methods and Materials}

\subsection{Descriptions of the study area}

The Dhidhessa River basin drains to the Blue Nile River (Figure 1). It is one of the largest and most important Blue Nile River basins in terms of its physiography and hydrology [41]. Located between $7^{\circ} 42^{\prime} 43^{\prime \prime} \mathrm{N}$ to $10^{\circ} 2^{\prime} 55^{\prime \prime} \mathrm{N}$ latitude and $35^{\circ} 31^{\prime} 23^{\prime \prime} \mathrm{E}$ to $37^{\circ} 7^{\prime} 60^{\prime \prime} \mathrm{E}$ longitude, the River basin exhibits highly variable topography that ranges from $619 \mathrm{~m}$ to $3213 \mathrm{~m}$ above mean sea level (a.m.s.l). The Dhidhessa River starts from Sigmo mountain ranges located in Jimma Zone, Oromia, Ethiopia and travels about $495 \mathrm{~km}$ before it joins the Blue Nile around the Wanbara and Yaso districts. The outlet considered for this study is at the confluence of the Dhidhessa River with the 
Blue Nile River that covers a total drainage area of $28,175 \mathrm{~km}^{2}$. The river basin has many perennial tributaries.

Temperature and rainfall in the Dhidhessa River basin exhibit substantial spatial and seasonal variability. The mean daily maximum and minimum air temperatures in the river basin range from $20-33^{\circ} \mathrm{C}$ and $6-19^{\circ} \mathrm{C}$, respectively. The mean annual rainfall ranges from $1200 \mathrm{~mm}$ to $2200 \mathrm{~mm}$ in the river basin. Soils in the river basin are generally deep and have high organic content implying they have high infiltration potential. The dominant soil type is Acrisols while Cambisols and Nitisols are common [42]. Igneous, sedimentary and metamorphic rocks are common in the basin with igneous rock, particularly basalt being dominant [43]. Forest, shrubland, grassland, and agriculture are the primary land cover types in the basin [40]. Major crops include perennial and cash crops like coffee, Mango and Avocado [42]. The river basin is notable for its plant and animal biodiversity.

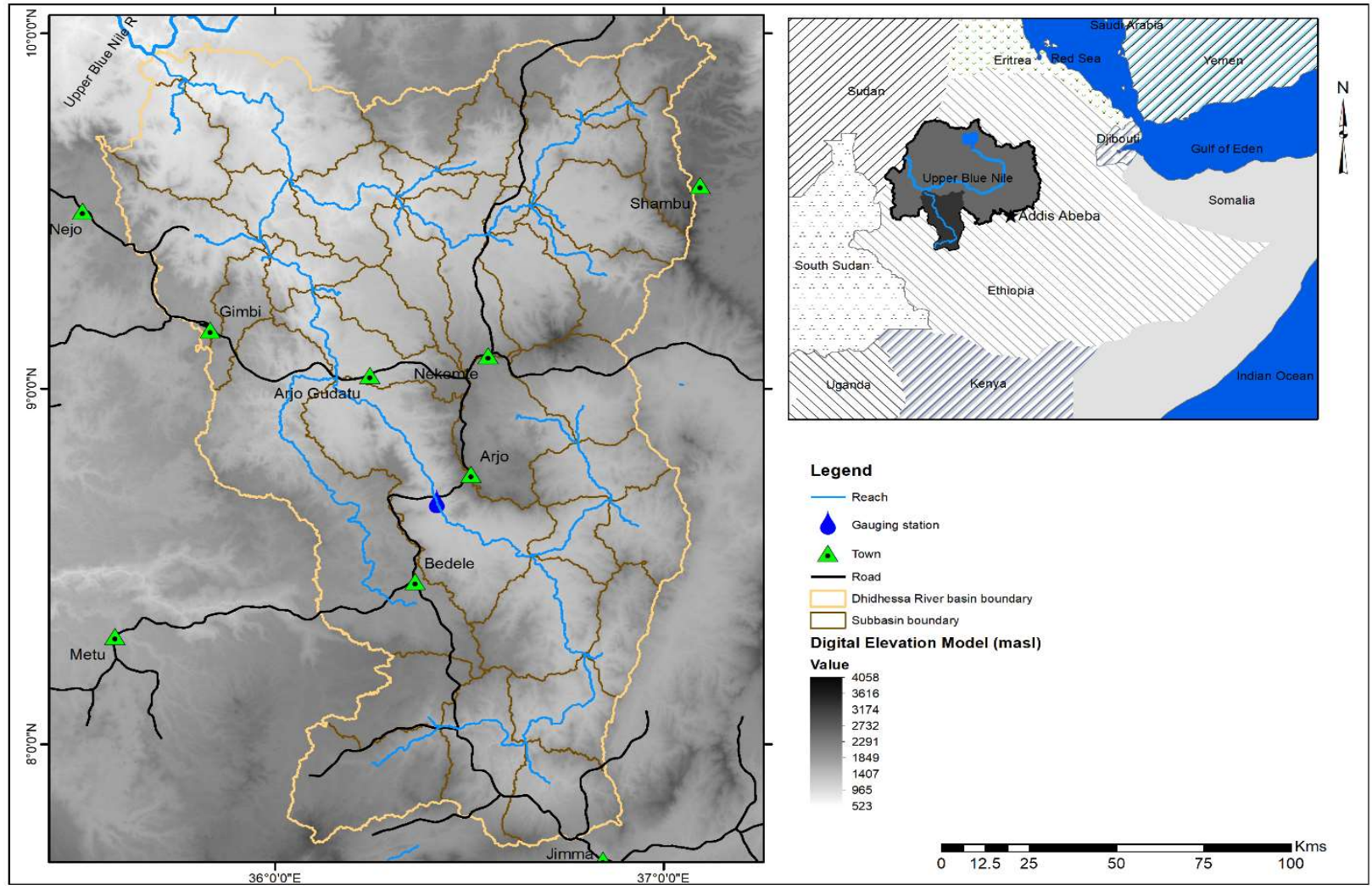

Figure 1. Location map of Dhidhessa River basin with ground stations. 


\subsection{Data sources and descriptions}

Shuttle Radar Thematic Mapper (SRTM) derived Digital Elevation Data (DEM) of 30*30 m spatial resolution was obtained from the United States Geological Survey (USGS), and was used to derive topographic and drainage parameters (e.g., drainage pattern, slope, and boundary) for the basin. Together with land cover and soil maps, the subbasins delineated from the DEM are used to create Hydrologic Response Units (HRUs). Land cover maps for 1985, 2001 and 2017 were obtained from Kabite et al.[40], and were used as input to calibrate the SWAT model and to examine the impacts of land cover change on hydrological response. Finally, soil map for the basin was obtained from the Ethiopian Ministry of Water, Irrigation and Energy (EMoWI). The soil physical properties required for SWAT model were derived from this soil map.

Rainfall and temperature (i.e., 1982 to 2018) data for the Dhidhessa River basin were derived from the Climate Hazards Group InfrareRed Precipitation with Stations version 2 (CHIRPS2) and the Enhanced National Climate Time-series Service (ENACTS), respectively. The spatial resolution of the datasets are $5 \mathrm{~km}$ and $4 \mathrm{~km}$, respectively and the full description of the datasets are described in Kabite et al. [39]. Kabite et al. [39] reported the suitability of these products for the Dhidhessa River basin. Climate change information done using these data was obtained from Kabite et al. [39]. Streamflow data for Dhidhessa River from 1982 to 2014 was obtained from Ethiopian Ministry of Water, Irrigation and Energy (MoWIE) for a station near the town of Arjo (Figure 1). Only one gauge station was used to calibrate and validate the SWAT model because most of the subbasin are generally ungauged. This is one of the limitation of this study. The streamflow data was used to calibrate SWAT as described in the section above. Generally, land cover and climate changes information for the Dhidhessa River basin were obtained from Kabite et al. [40] and Kabite et al. [39], respectively.

\subsection{Methodology}

Distributed process-based hydrological models are effective for assessing the separate and combined impacts of land cover and climate changes on hydrological processes [44]. Soil and Water Assessment Tool (SWAT) is a semi-distributed process-based hydrological model that was developed to predict the impacts of land management practices on water, sediment, and 
agricultural chemical yields [45]. It is now widely used for various applications throughout the world including in the Blue Nile basin for water balance studies, soil erosion, land cover or climate change impact assessment $[46,47,48]$. The capability of SWAT to characterize hydrologic responses of a basin for various land-use and climate change scenarios was well documented [1,3, 49,50]. The deterministic nature of SWAT makes the model suitable to separate the contributions of climate and land cover changes on hydrologic response [33]. As such, SWAT was used in this study. As previously described, spatial datasets such as land cover, DEM and soil and the temporal datasets like weather data (i.e., rainfall and temperature), obtained from various sources were used to setup and calibrate SWAT.

\subsubsection{Description of SWAT}

SWAT is designed to operate at various spatiotemporal scales, environmental conditions, and different spatial and temporal details [47]. SWAT is integrated with Geographic Information System (GIS) and handles the spatiotemporal heterogeneity of basin characteristics such as topography, land cover, soil and climate condition [32,51]. For this study, SWAT model was carried out at monthly timescale. In addition, a tool known as SWAT-CUP simplifies calibration, sensitivity analysis and uncertainty analysis of SWAT model. Unlike many distributed models, SWAT is not data intensive [52]. As such, SWAT is suitable for data scarce basins like Dhidhessa River basin. SWAT simulates hydrological responses using water the balance equation as,

$$
S W_{t}=S W_{o}+\sum_{i=0}^{t}\left(R_{\text {day }}+Q_{\text {surf }}-E_{a}-W_{\text {seep }}-Q_{q w}\right)_{i}
$$

where $S W_{t}$ is the final soil water content $(\mathrm{mm}), S W_{0}$ is the initial soil water content on day $i$ $\left(\mathrm{mm} \mathrm{H}_{2} \mathrm{O}\right), t$ is the time (days), $R_{\text {day }}$ is the amount of precipitation on day $\mathrm{i}\left(\mathrm{mm} \mathrm{H}_{2} \mathrm{O}\right), E_{a}$ is the amount of evapotranspiration on day $i\left(\mathrm{~mm} \mathrm{H}_{2} \mathrm{O}\right), W_{\text {seep }}$ is the amount of water entering the vadose zone from the soil profile on day $i\left(\mathrm{~mm} \mathrm{H}_{2} \mathrm{O}\right)$ and $Q_{q w}$ is the amount of return flow on day $i(\mathrm{~mm}$ $\left.\mathrm{H}_{2} \mathrm{O}\right) . Q_{\text {surf }}$ is the amount of surface runoff or rainfall excess on day $i(\mathrm{~mm})$, and is calculated as,

$Q_{\text {surf }}=\frac{\left(R_{\text {day }}-0.2 S\right)^{2}}{\left(R_{\text {day }}+0.8 S\right)}$, if $R_{\text {day }}>0.2 \mathrm{~S} ; Q_{\text {surf }}=0$ otherwise

$\mathrm{S}$ is the retention parameter $(\mathrm{mm})$ described as,

$S=25.4\left(\frac{100}{C N}-10\right), C N$ is the curve number for the day 
SWAT uses a two-level discretization scheme: i) sub-basin creation based on topographic information, and ii) Hydrological Response Unit (HRU) creation by further discretizing of the subbasins based on land use, soil type slope classes. HRU is a basic computational unit assumed to have homogeneous hydrologic response. Hydrological processes are first simulated at the HRU level and then routed through the reaches using the Muskingum routing method [45]. SWAT estimates surface runoff using the modified United State Department of Agriculture (USDA) SCS curve number method (Eq. 2 and 3), and potential evapotranspiration using the Hargreaves method. In this study, a minimum threshold area of $400 \mathrm{~km}^{2}$ was used for determining the number of subbasins, and 5\% threshold for soil, slope, and land use were used for the HRU definition. Consequently, the Dhidhessa River basin was discretized in to 41 subbasins and 800 HRUs.

\subsubsection{SWAT model calibration}

SWAT model should be calibrated before using the model output for any application. SWAT-CUP is one of the widely used software for SWAT model calibration [54]. The Sequential Uncertainty Fitting: SUFI-2 algorithm (SUFI-2) available from SWAT-CUP was used for the calibration effort. SUFI-2 provides more reasonable and balanced predictions than the generalized likelihood uncertainty estimation (GLUES) and the parameter solution (ParaSol) methods also supported by SWAT-CUP [53,55].

Determining the most sensitive parameters for a given watershed is the first requirement for SWAT model calibration. For this study, 19 parameters were considered for calibration based on recommendations by previous studies [56,57]. Global sensitivity analysis was performed using SWAT-CUP on the parameters, and 11 were deemed sensitive for the Dhidhessa River basin. Then, the SWAT model was calibrated for the streamflow data from the station near Arjo town for the land cover reference years of 1985 (i.e., 1984 to 1990 period), 2001 (i.e., 2003 to 2008 period) and 2017 (i.e., 2009 to 2014 period). It was assumed that land cover change is less significant within short periods of time. In addition, the purpose of these calibrations are to obtain land cover specific parameter values for each study periods and used for the later simulations. In all the cases,

2 years of warm-up period was used to initialize the model. Since there is no measured streamflow at or near the basin outlet, the calibrated parameter values were transferred to the downstream subbasins. 
Graphical and statistical goodness-of-fit measures were used to evaluate quality of the model predictions for the Dhidhessa River basin. Accordingly, the performance of SWAT models for the 1985, 2001 and 2017 reference years were tested for monthly timescale using the most widely used measures (i.e., coefficient of determination, $R^{2}$; Nash-Sutcliffe coefficient of efficiency, NSE; and Percent bias, $P B I A S$ ) [62]. $R^{2}$ shows how well the variance of observed values are simulated by the model predictions. The NSE indicates model fit between the simulated and observed discharge while PBIAS measures the average tendency of the forecast values to be larger or smaller than their observed ones. In addition, the total uncertainty in the model prediction is commonly measured by $P$ - and $R$-factor. $P$-factor represents the percentage of observed data enveloped by our modelling result, the 95 percent prediction uncertainty (95PPU). And the $R$ factor represents the ratio of the average width of the 95PPU band to the standard deviation of observed data. For the realistic model prediction, $P$-factor $\geq 0.7$ and $R$-factor $\leq 1.5$ is required $[54,58]$.

\subsubsection{Simulation Scenarios}

The following procedure was employed to assess the separate and combined impacts of land cover and climate changes on hydrological response. First, the climate data was divided in to three (i.e., 1982 to 1995,1995 to 2008 and 2008 to 2018) based on a trend analysis we did on the climate data [39]. Next, SWAT model was calibrated for each land cover reference map, and was used to a baseline model and models for the eight land cover-climate change scenarios shown in Table 1. Finally, results for each scenarios were compared to the baseline results, and then relative impacts of land cover change and climate change were quantified.

To assess the separate impacts of land cover and climate changes on hydrological processes, scenario models were developed using the "one-factor- at- a-time" approach in which one factor is changed at a time while fixing the other condition $[4,16]$. Such technique helps to separate the relative contributions of land cover and climate change impacts. On the other hand, the combined impacts of the land cover and climate changes was assessed from scenario models developed by changing both land cover and climate. To develop the scenarios, CHIRPS2 rainfall and ENACTS temperature data were split into three periods as shown in Table 1. 
Table 1. Scenario model experiments.

\begin{tabular}{llll}
\hline Scenarios & Land cover & Climate & Remarks \\
\hline 1 & 1985 & $1982-1995$ & Baseline \\
2 & 2001 & $1982-1995$ & Land cover impact \\
3 & 1985 & $1995-2008$ & Climate change impact \\
4 & 2001 & $1995-2008$ & Combined impact and/or baseline \\
5 & 1985 & $2008-2018$ & Climate change impact \\
6 & 2001 & $2008-2018$ & Combined impact \\
7 & 2017 & $1982-1995$ & Land cover impact \\
8 & 2017 & $1995-2008$ & Combined impact \\
9 & 2017 & $2008-2018$ & Combined impact \\
\hline
\end{tabular}

Separating the relative contribution of land cover and climate changes impacts on hydrological responses is crucial for sustainable watershed management and uses. In the absence of such information, the positive impacts of land cover change can mask the negative impacts of climate change and vice versa. Studies have employed different methods to separate the relative contributions of land cover and climate changes [3]. For this study, a statistical method recommended by Yin et al. [34], and described in equations 5 and 7 was adopted.

$$
\begin{aligned}
\Delta H_{\text {comb }} & =\left(\frac{S_{\text {base }, i+1}-S_{\text {base }, i}}{S_{\text {base }, i}}\right) * 100, \\
\Delta H_{\text {sep }, L c} & =\left(\frac{s_{\text {sim }, L c, i}-S_{\text {base }, i}}{s_{\text {base }, i}}\right) * 100, \\
\Delta H_{\text {sep }, c c} & =\left(\frac{S_{\text {sim }, c c, i}-S_{\text {base }, i}}{S_{\text {base }, i}}\right) * 100
\end{aligned}
$$

where $\Delta H_{\text {comb }}$ : the combined impacts of land cover and climate changes (in \%); $S_{b a s e, i+1}$ : simulation with changing both land cover and climate from the baseline reference years; $S_{b a s e, i}$ : baseline simulation; $\Delta H_{s e p, L c}$ : the separate impacts of land cover change; $S_{s i m, L c, i}:$ simulation with the same climate with the baseline simulation while changing the land cover; $\Delta H_{s e p, c c}$ : the separate impacts of climate changes; $S_{s i m, c c, i}$ : simulation with the same land cover with the baseline simulation while changing the climate reference year. 
In summary, the separate and combined effects of the land cover and climate changes were quantified as follows.

i. Scenario 1 was considered baseline for the three periods while scenario 4 was used as baseline for the 2008 to 2018 period.

ii. The separate impacts of land cover changes were determined by comparing results of scenario 2 and scenario 1, scenario 8 and scenario 4, and scenario 7 and scenario 1 .

iii. The separate impacts of climate change was determined by comparing scenarios 3 and 1 , scenarios 6 and 4 and scenarios 5 and 1 .

iv. The combined impacts of land cover and climate changes was determined using scenario 4 and 1 , scenario 9 and 4 , and scenario 9 and 1 .

\section{Results}

\subsection{SWAT model calibration}

Table 2 shows calibrated parameters and their ranges of values considered reasonable, bestfit values, and sensitivity ranks for the three land cover maps used in this study. The table shows that the acceptable ranges and optimal values vary from one land cover data to the other. This indicates the sensitivity of hydrological responses of the basin to land cover, and/or the capability of SWAT to characterize hydrological responses of a land cover changes. Relative sensitivity of the parameters also varied among land cover data. For all three land cover maps, manning's " $n$ " for the main channel ( $\left.\mathrm{CH}_{-} \mathrm{N} 2 . r t e\right)$, effective hydraulic conductivity of the main channel alluvium ( $C H \_$K2.rte), threshold depth of water in the shallow aquifer required for return flow to occur $(G W Q M N . g w)$ and baseflow alpha factor $\left(A L P H A \_B F . g w\right)$ were the most sensitive parameters for the Dhidhessa River basin. These parameters have relevance to the groundwater flux indicating that subsurface hydrological processes are influential in the basin. This is also confirmed by the relatively high baseflow ratios simulated by all three scenarios (i.e., $0.88,0.88$ and 0.84 respectively). Baseflow ratio of observed streamflow is high (i.e., 0.86) further confirming dominance of subsurface flux in the Dhidhessa River basin (Figure 2). The dominant baseflow in the Dhidhessa River basin is also reported by previous studies [41,59-61]. As previously described, 
the basin has deep soil, permeable lithology, is vegetated and receives high rainfall. All these characteristics favor high infiltration and percolation thus resulting in substantial baseflow.

Table 2. Calibrated parameters behavioral ranges, best-fit values, and their sensitivity ranks for various land covers.

\begin{tabular}{|c|c|c|c|c|c|c|c|c|c|c|c|c|}
\hline \multirow[b]{2}{*}{ Parameters } & \multicolumn{4}{|c|}{ Land cover of 1985} & \multicolumn{4}{|c|}{ Land cover of 2001} & \multicolumn{4}{|c|}{ Land cover of 2017} \\
\hline & Min & Max & Fitted & Rank & Min & Max & Fitted & Rank & Min & Max & Fitted & Rank \\
\hline v_CH_N2.rte & -0.02 & 0.16 & 0.07 & 1 & 0.03 & 0.12 & 0.07 & 1 & 0.06 & 0.10 & 0.08 & 1 \\
\hline v_CH_K2.rte & 314.74 & 450.43 & 355.82 & 2 & 290.46 & 396.88 & 373.29 & 2 & 167.13 & 265.01 & 216.07 & 2 \\
\hline v_GWQMN.gw & 1145.82 & 2102.38 & 1479.02 & 3 & 1056 & 1356.54 & 1200 & 3 & 1435.12 & 2202.31 & 1818.71 & 3 \\
\hline v_GW_REVAP.gw & 0.02 & 0.12 & 0.05 & 4 & 0.14 & 0.2 & 0.18 & 8 & 0.12 & 0.17 & 0.15 & 4 \\
\hline v_ALPHA_BF.gw & 0.00 & 0.45 & 0.08 & 5 & 0.00 & 0.49 & 0.09 & 4 & 0.00 & 0.23 & 0.09 & 5 \\
\hline r_SOL_AWC.sol & -0.05 & 0.32 & 0.22 & 7 & 0.04 & 0.18 & 0.17 & 6 & -0.01 & 0.2 & -0.15 & 6 \\
\hline v_GW_DELAY.gw & 16.25 & 28.75 & 24.44 & 6 & 8.65 & 26.22 & 18.98 & 5 & 13.57 & 20.71 & 17.14 & 7 \\
\hline v_RCHRG_DP.gw & 0.32 & 0.69 & 0.56 & 9 & 0.01 & 0.49 & 0.34 & 7 & 0.19 & 0.58 & 0.39 & 8 \\
\hline r_CN2.mgt & 0.02 & 0.1 & 0.08 & 8 & 0.00 & 0.15 & 0.09 & 11 & 0.00 & 0.2 & 0.1 & 9 \\
\hline r_SOL_K.sol & 380 & 750 & 600 & 10 & 910.46 & 1036.88 & 912.77 & 9 & 1629.06 & 1805.18 & 1717.12 & 10 \\
\hline v_REVAPMN.gw & 136.40 & 209.27 & 146.48 & 11 & 95 & 150 & 120 & 10 & 174.14 & 275.23 & 224.96 & 11 \\
\hline
\end{tabular}

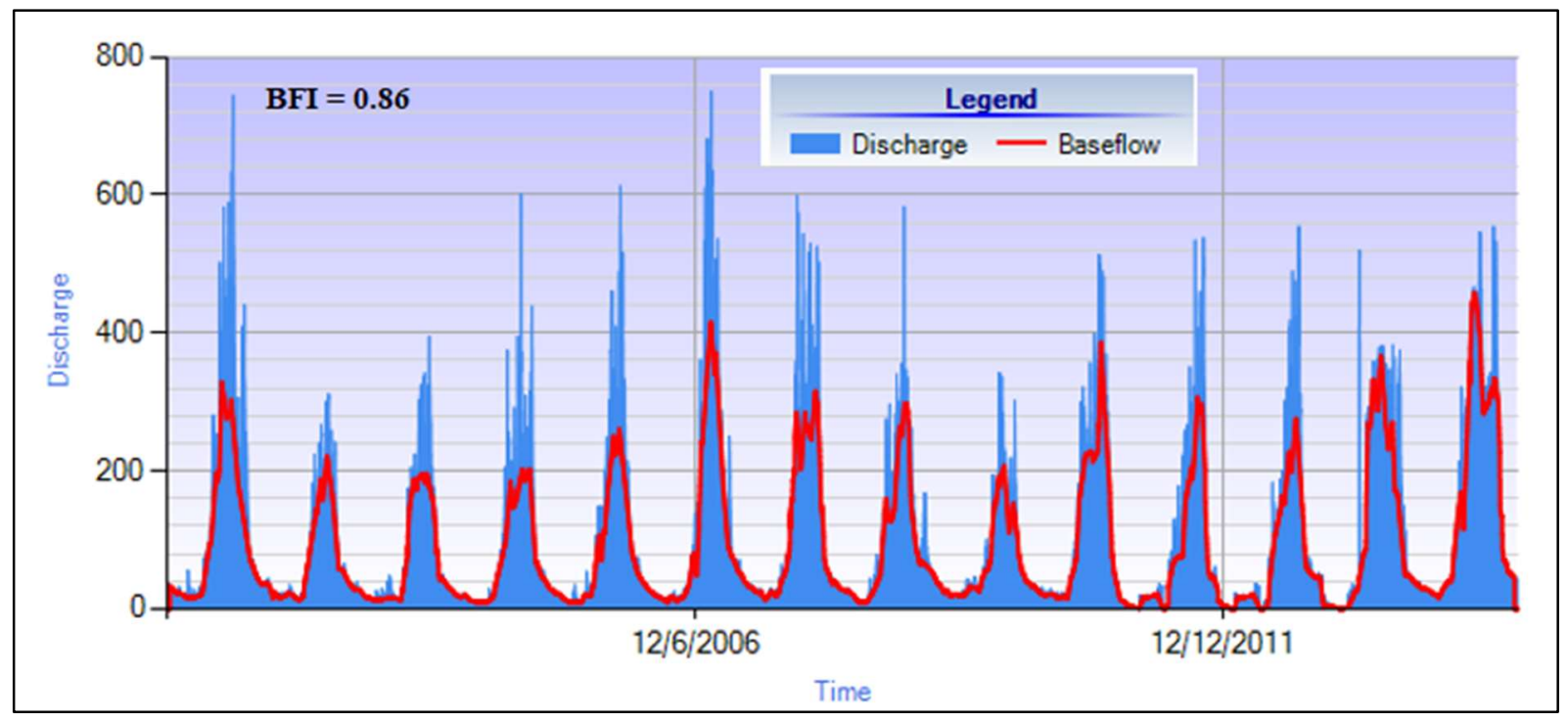

Figure 2. Baseflow separation from the observed streamflow.

Figure 3 shows graphical calibration results for the 1985, 2001 and 2017 land covers. The figure shows that the observed streamflow is in good agreement with the simulated streamflow. However, peak flow was underestimated and streamflow volume was overestimated by all three models. Limited capability of the satellite-based rainfall data used for this study to characterize 
spatiotemporal variability of rainfall in the basin and SWAT model uncertainty could be the primary reason for underestimating peak flow and overestimating streamflow volume.

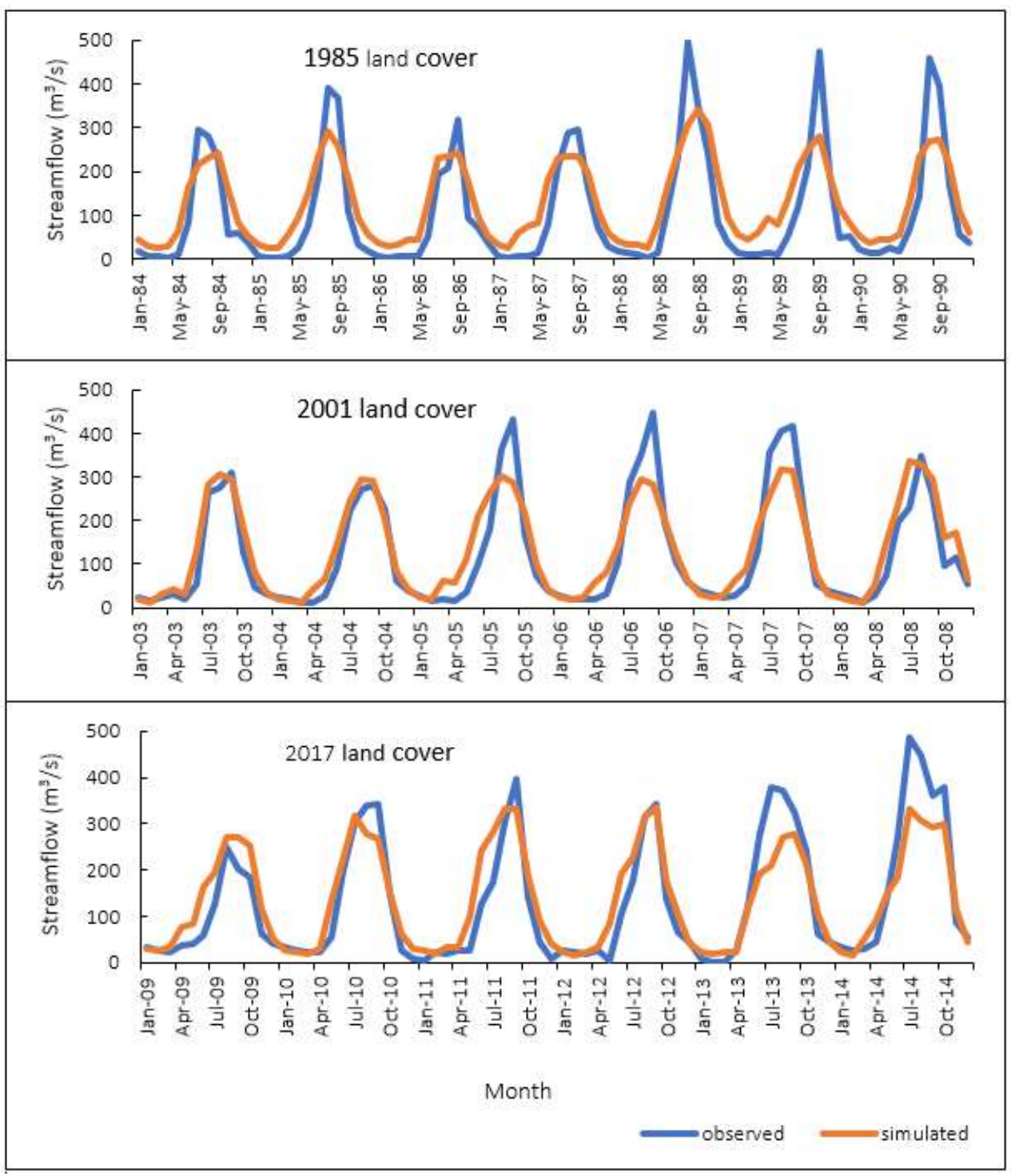

Figure 3. Comparison of observed and SWAT simulated monthly streamflow for three different land covers.

Table 3 shows additional information to evaluate performance of the statistical calibrated model for the 1985, 2001 and 2017 land covers. The result showed $N S E \geq 0.7, P B I A S< \pm 15$ and $R^{2}$ $\geq 0.7$ for all models, which shows very good model performance according to Moriasi et al. [62] model performance classification. Moreover, the $P$-factor and $R$-factor values for all models are acceptable [62]. Overall, both the statistical measurements shown in Table 3 and the graphical 
results shown in Figure 2 indicate that streamflow predictions of the calibrated models are in good agreement with the observed streamflow. This indicates that the models can represent hydrological response of the Dhidhessa River basin and are suitable for further application.

Table 3. Values of Statistical Measures Obtained for the Calibrated Models.

\begin{tabular}{llll}
\hline Statistical measures & 1985 land cover & 2001 land cover & 2017 land cover \\
\hline$P$-factor & 0.62 & 0.76 & 0.71 \\
$R$-factor & 0.84 & 0.99 & 0.91 \\
$N S E$ & 0.74 & 0.85 & 0.75 \\
$R 2$ & 0.82 & 0.86 & 0.74 \\
$P B I A S$ & -14.4 & -8.7 & -1.4 \\
Mean sim. (Mean obs.) & $119.48(104.17)$ & $133.73(123.09)$ & $132.47(130.64)$ \\
\hline
\end{tabular}

\subsection{Hydrologic responses to land cover and climate changes}

The hydrological responses to land cover and climate changes for the 1982-1995 to 19952008, $1995-2008$ to $2008-2018$ and $1982-1995$ to $2008-2018$ periods were calculated by comparing the predictions of scenarios 1 and 4, scenarios 4 and 9, and scenarios 1 and 9, respectively. Figure 4 shows results of the analysis. From 1982-1995 to 2008-2018 surface runoff, streamflow and AET increased by $40 \%, 4 \%$ and $5 \%$, respectively while groundwater recharge declined by 3\%. Surface runoff and AET increased during both 1982-1995 to 1995-2008 and 19952008 to 2008-2018 period. Even though, the percentage increase in surface runoff seems high (i.e., 40 ), increase in the magnitude of surface runoff is modest (increased from $96 \mathrm{~mm}$ to $134 \mathrm{~mm}$ ).

The overall water balance for the 1982-1995 to 2008-2018 period shows that surface runoff to streamflow ratio is 14 percent. Subsurface flows (i.e., lateral flow and groundwater flow) account for $86 \%$ of streamflow in the basin. To be more specific, AET, surface runoff, lateral flow, and groundwater flow account for $41,8,42$, and 4 percent of the rainfall, respectively. The water balance breakdown is similar for the 1982-1995 to 1995-2008 and 1995-2008 to 2008-2018 periods as well. 


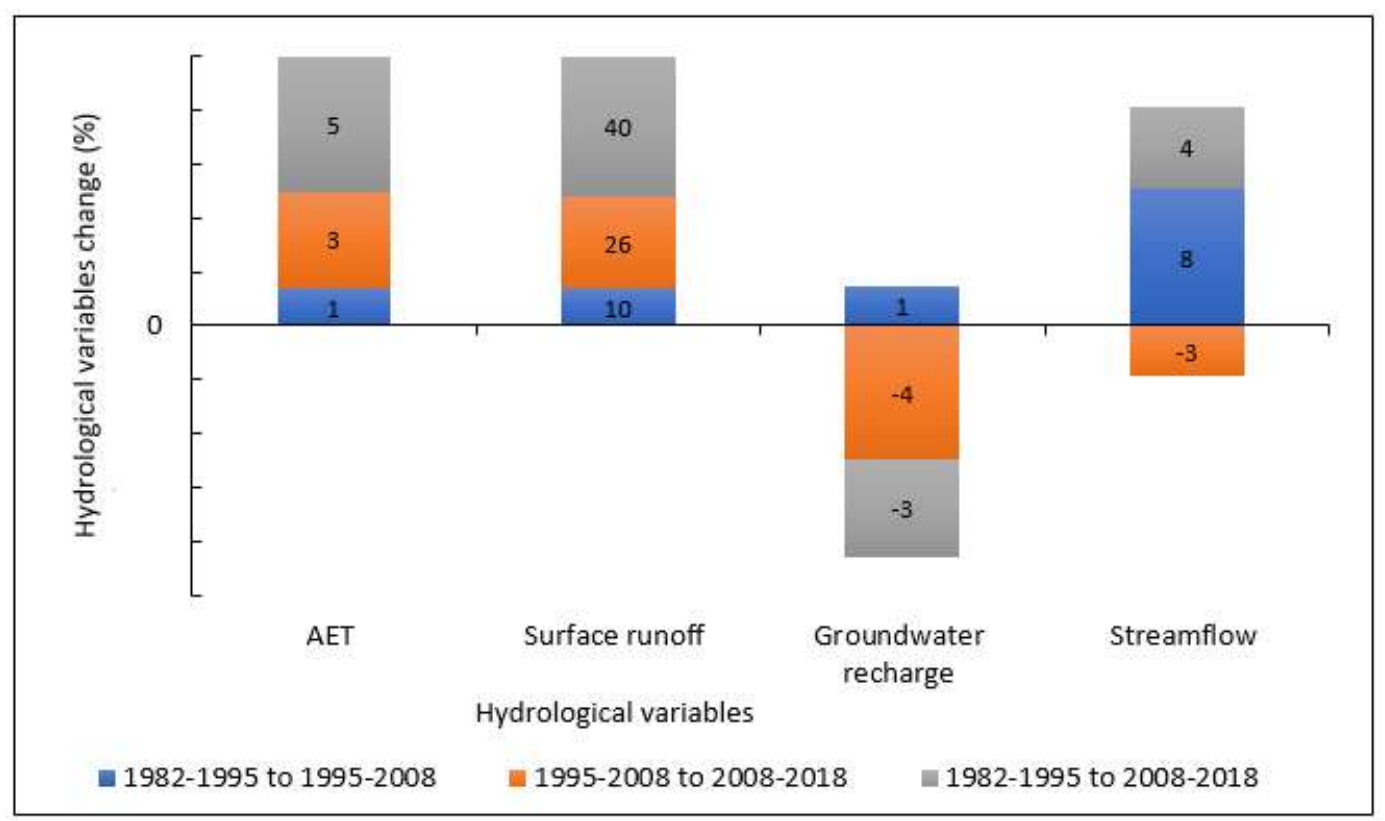

Figure 8 . Changes in hydrological response to land cover and climate changes.

\subsection{Relative contributions of the separate and combined impacts of land cover and climate changes on hydrologic responses}

Relative contributions of the separate and combined effects of land cover and climate changes on hydrological responses were calculated based on equations 5 to 7 (Table 4). Results show that the relative contributions vary among the hydrological variables and the study periods. For example, climate change increased AET while land cover change decreased the variable. Land cover change increased surface runoff but decreased groundwater recharge. On the other hand, the effect of land cover and climate changes on other hydrologic responses vary among study periods. Surface runoff was more sensitive to land cover change than to climate change. AET and streamflow were more sensitive to climate change than to land cover change. The relative importance of land cover and climate change on groundwater recharge vary among study periods. The combined effects was more important than the separate effect on surface runoff and AET during the 1982-1995 to 2008-2018 and 1995-2008 to 2008-2018, respectively. On the other hand, the combined effect and the effect of climate change was identical for streamflow during all periods. 
Table 4. Relative contributions of separate \& combined effects of land cover and climate changes.

\begin{tabular}{lccccccccc}
\hline & \multicolumn{3}{c}{1982 to 2001} & \multicolumn{3}{c}{2001 to 2018} & \multicolumn{3}{c}{1982 to 2018} \\
\cline { 2 - 10 } Hydrologic & $H_{\text {sep }, c c}$ & $\Delta H_{\text {sep }, L c}$ & $\Delta H_{\text {comb }}$ & $\Delta H_{\text {sep }, c c}$ & $\Delta H_{\text {sep }, L c}$ & $\Delta H_{\text {comb }}$ & $\Delta H_{\text {sep }, c c}$ & $\Delta H_{\text {sep }, L c}$ & $\Delta H_{\text {comb }}$ \\
\multicolumn{1}{c}{ variables } & $(\%)$ & $(\%)$ & $(\%)$ & $(\%)$ & $(\%)$ & $(\%)$ & $(\%)$ & $(\%)$ & $(\%)$ \\
\hline AET & 2.4 & -0.9 & 1.4 & 2.8 & 0.4 & 3.4 & 5.3 & -0.3 & 4.8 \\
Runoff & 9.4 & 1.2 & 10.4 & -8.5 & 38.7 & 26.4 & 2.1 & 36.5 & 39.6 \\
Recharge & 8.0 & -7.4 & 1.2 & -4.8 & -1.2 & -4.2 & 3.7 & -7.4 & -3.1 \\
Yield & 7.0 & 0.5 & 7.5 & -2.3 & -0.5 & -2.9 & 4.7 & -0.1 & 4.4 \\
\hline
\end{tabular}

Another interesting finding of this study is that the combined effects of land cover and climate changes played synergistic effect for some hydrologic variables and offsetting effect for other variables. For example, the combined effect played synergistic effect on surface runoff for the 1982-1995 to 1995-2008 and 1982-1995 to 2008-2018 while offsetting effect for the 19952008 to 2008-2018 study periods. A substantial land cover change combined with a trivial change in climate from 1982-1995 to 2008-2018 resulted in higher surface runoff. On the other hand, for the 1995-2008 to 2008-2018 period, the decrease in surface runoff caused by a declining rainfall was offset by the increase caused by the loss of vegetation cover. However, the combined impacts of land cover and climate changes had offsetting effect on groundwater recharge and AET during the same period. Climate change decreased groundwater recharge and AET but land cover change increased the two hydrological variables during 1982-1995 to 1995-2008 and 1982-1995 to 20082018.

\section{Discussion}

This study showed that SWAT model is suitable for studying the impacts of land cover and climate changes on hydrologic responses for the Dhidhessa River basin. The performance of the model was very good for the basin based on Moriasi et al. [62] model performance classification. The high baseflow ratio for the three simulated scenarios and observed streamflow showed that basflow is the major contributors for the Dhidhessa River streamflow. This has also been reported by several previous studies [41,59-61]. As previously described, the basin has deep soil, permeable lithology, is vegetated and receives high rainfall. All these characteristics favor high infiltration and percolation thus resulting in substantial baseflow. 
The changes in hydrologic responses observed in this study is attributed to the land cover and climate changes of the Dhidhessa River basin. Substantial spatiotemporal land cover and climate changes were reported during the last three decades in the Dhidhessa River basin [39, 40]. For example, agriculture, settlement, and water bodies increased while bush and shrubland, and forest lands decreased from 1985 to 2001 . Grassland increased from 1985 to 2001 but declined from 2001 to 2017. From 1985 to 2017, agriculture, grassland, settlement and waterbody increased by $265 \%, 43 \%, 106 \%$ and $525 \%$ while forest and bush and shrubland declined by $20 \%$ and $47 \%$, respectively. In addition, the result showed that about $47 \%$ of the study areas undergone land cover transformation from one land cover to other during the last three decades where most of the transformation was from natural vegetation to agricultural land [40]. The land cover changes were mainly driven by both anthropogenic (i.e., population pressure) and biophysical factors (i.e., climate and topography). Population pressure, attributed mainly to the 1985 and 2002/3 settlement programs, and economic activities such as agricultural investments and construction of surface water reservoirs were the primary drivers of land cover changes in the Dhidhessa River basin for the 1982 to 2017 period [40]. The basin mainly experienced conversion of natural vegetation to agricultural land. This could increases surface runoff, reduces groundwater recharge, aggravates soil erosion, and limits water resource availability [48,63-65]. Shawul et al. [48] reported that conversion of vegetation to urban and cropland increased runoff but decreased groundwater recharge in the upper Awash basin. Likewise, the conversion of natural vegetation to agricultural land leads to decreasing dry season flow and increasing wet season flow, which have negative impacts on the environment and agricultural production [66]. Likewise, the wetting and warming climatic condition observed in the Dhidhessa River basin will have a positive implications for agriculture and water resources availability. However, the combined effects of climate and land cover changes may diffuse the positive impacts, particularly on water resources. Likewise, climate changes was reported in the Dhidhessa River basin during the last three decades [39]. Rainfall generally increased but statistically significant increasing trends was reported in some parts of the Dhidhessa River basin. On the other hand, statistically significant increasing trends of both minimum and maximum temperature were reported during the last three decades in the river basin. Generally, wetting and warming of Ddhidhessa River basin was reported for the Dhidhessa River basin during the last three decades [40]. 
We think surface runoff increased in the Dhidhessa River basin primarily because of increase in agricultural land (by 265\%) at the expense of declines in bush and shrub by $47 \%$ and forestland by $20 \%$. In addition, increasing rainfall in the basin during the analysis period has also contributed for the increased surface runoff. Losses of natural vegetation increase surface runoff by reducing infiltration and time of concentration. Agricultural activities could disturb soil structure and reduce soil infiltration capacity resulting in high volume of runoff production $[67,68]$. Thus, we believe land cover changes coupled with increased rainfall has led to increased surface runoff in the Dhidhessa River basin. Decreased in infiltration also explains the decline in ground water recharge during the study period. Vegetation cover influences groundwater recharge as it promotes infiltration and percolation by modifying soil structure and by slowing down surface flow. This finding is in line with Shawul et al. [48] who reported strong correlations between vegetation cover and groundwater recharge.

Decrease in streamflow during 1995 -2008 to 2008-2018 and slight increase during 19821995 to 2008-2018, despite increase in surface runoff, can be attributed to the decline in groundwater recharge. As previously mentioned, baseflow contributes about $86 \%$ streamflow for the Dhidhessa River basin. The result is in agreement with previous study in the basin [60]. The increasing surface runoff while decreasing streamflow show that wet season flows exhibited increasing trend while dry season flows are declining. This trend can be the result of a declining baseflow. This finding is consistent with Brook et al. [69] who reported increase in streamflow during wet season and decline during dry season for Anger catchment, which is in the Dhidhessa River basin. Increase in surface runoff (wet season flow) and decline in groundwater recharge (dry season flow) would have negative impacts on agricultural production and water resources availability [66]. Higher surface runoff during wet season aggravates flooding and soil erosion, both impact agricultural activity adversely. Low dry season flows worsen water resource scarcity. The findings of this study is consistent with previous studies [22,70,71]. For example, Chimdessa et al. [70] reported increasing streamflow in the Dhidhessa River basin. Berihun et al. [71] reported increased surface runoff in response to land cover change in the upper Blue Nile basin.

The findings of this study on the relative contribution of land cover and climate changes are in agreement with previous studies reported in the upper Awash basin [48] and in Heihe River basin [22]. Several studies have reported that surface runoff is more sensitive to land cover change 
than to climate change $[4,34,71]$. In contrary, there are studies that have argued that surface runoff is more sensitive to climate change than to the land cover change [22,72]. Similarly, a study of small watershed located in the upper Blue Nile basin showed that AET is more sensitive to land cover change than to climate change [71]. This study also showed that streamflow in the Dhidhessa River basin is more sensitive to climate change than to land cover change. This finding is consistent with several previous studies [22,70,73], and disagrees with findings of others [4, 34]. This implies that relative sensitivity of streamflow to climate change and land cover could vary from basin to basin. This underscores the challenges to generalize relative impacts of the changes and the need to analyze impacts on basins and various hydrologic variables on a case-by-case basis.

The combined impacts of land cover and climate changes on hydrologic responses reported in this study are consistent with findings of Tamm et al. [74] and Berihun et al. [71]. Studies showed that the offsetting and synergetic effects of land cover and climate changes on hydrological variables depends on the severity of the changes and on basin characteristics $[22,75,76]$. The result also showed that surface runoff was more sensitive to land cover and climate changes during the last three decades in the Dhidhessa River basin.

Overall, the hydrological responses of the Dhidhessa River basin has undergone significant changes during the last three decades. The changes in hydrologic regimes are indicators of changes in watershed conditions [77]. Increase in surface runoff and decrease in groundwater recharge in the Dhidhessa River basin indicates deterioration of land resources in the basin. Increased surface runoff aggravates soil erosion, reservoir siltation, and deteriorates water quality. As such, we think changes in land cover and climate have adverse impacts on agricultural production and water resource availability in the Dhidhessa River basin. The problem could be more severe as the trend continuous $[39,40]$.

If carefully planned and implemented, integrated watershed management and climate adaptation strategies reverse the negative impacts. Soil and water conservation practices and afforestation could play key roles in reversing the impacts. Conservation measures reduce surface runoff by slowing down runoff and by enhancing infiltration and percolation. They also maintain or improve soil fertility and create favorable condition for the soil to support vegetation growth and hold water. Finally, afforestation could modify the climatic condition of the area and the 
surroundings. Generally, afforestation and soil and water conservation practices could combat climate change and watershed degradation, and improve agricultural production and water resource availability.

\section{Conclusions}

An integrated study that assesses the spatiotemporal land cover and climate changes, and their separate and combined impacts on various hydrological responses is important to plan land resources management strategies. This study examined the impacts of the substantial land cover and climate changes reported for the Dhidhessa River basin during the last three decades. The study result completed for the Dhidhessa River basin showed that the majority of the land cover changes involves conversion from natural vegetation to agriculture land. This type of land cover conversion has significant impacts on hydrologic responses of a basin. Similarly, previous study result showed that rainfall and temperature were generally increased in the basin during the past three decades. Overall, the significant land cover and climate changes reported for the Dhidhessa River basin during the last three decades, and their complex interactions have resulted in a significant changes in hydrological responses.

SWAT was calibrated for all land cover conditions for this study. The calibration results showed that the model is suitable to examine the separate and combined effects of the land cover and climate changes on hydrologic responses for the Dhidhessa River basin. Our study shows that in response to the observed land cover and climate changes in the basin, surface runoff, AET and streamflow increased by $40 \%, 5 \%$ and $4 \%$ whereas groundwater recharge declined by $3 \%$, respectively during the last three decades. We think surface runoff increase was attributed to increase in rainfall and conversion of natural vegetation to agricultural land. Conversely, decline in groundwater recharge could be due to reduced infiltration and baseflow in response to conversion of vegetation cover to agriculture. Increased AET despite deforestation could be attributed to increased waterbody and crops in the basin. Streamflow increased during wet season but decreased during dry season dry season during the 1982-1995 to 2008-2018 period. These changes affect both agricultural activities and water resources availability negatively. 
The relative contribution of land cover and climate changes on hydrological responses is not consistent among the hydrologic variables. AET and streamflow were more sensitive to climate change than to land cover change whereas runoff was more sensitive to land cover change than to the climate change. The combined effects of land cover and climate changes had offsetting effect on groundwater recharge and AET. On the other hand, the combined effect had synergistic effect on surface runoff during 1982-1995 to 1995-2008 and 1982-1995 to 2008-2018 but offsetting effect during 1995-2008 to 2008-2018. On water yield, the combined effect had synergistic effect during 1982-1995 to 1995-2008 and 1995-2008 to 2008-2018 while offsetting effect during 19821995 to 2008-2018. The study showed that the combined effects of land cover and climate changes on hydrologic responses could be synergistic or offsetting depending on the severity of the land cover and climate changes, and basin characteristics.

Generally, in response to significant land cover and climate changes reported for the Dhidhessa River basin during the last three decades, significant hydrologic response changes were predicted. The simulated hydrologic responses have negative impacts on agricultural production and water resources availability. Future hydrologic regime could get worse if the land cover and climate changes trends continue [39]. Integrated watershed management strategies could reverse these problems.

Supplementary Materials: Provided up on request.

Author contributions: Conceptualization, Data collection, analysis and interpretation, writingoriginal draft preparation: Gizachew Kabite; Writing-review and editing. All authors have read and agreed to the published version of the manuscript: Misgana K. Muleta and Berhan Gessesse.

Funding: This research received no external funding.

Acknowledgments: We are grateful to the Ethiopian Space Science and Technology Institute for providing partial financial support for this research. We are also thankful to the developers of CHIRPS2, SRTM DEM and Landsat8 datasets and for providing the data free of charge. The National Meteorological Agency of Ethiopia and the Ethiopian Ministry of Water, Irrigation and Energy are also acknowledged for providing climate and streamflow data, respectively. 
Conflicts of Interest: The authors declare no conflict of interest.

\section{References}

1. Shi, P., Ma, X., Hou, Y., Li, Q., Zhang, Z., Qu, S., Chen, Ch., Cai, T., and Fang, X. 2013. Effects of land-use and climate change on hydrological processes in the Upstream of Huai River, China. Water Resource Manage, 27(5):1263-78.

2. Molina-Navarro, E., Trolle, D., Martínez-Pérez, S., Sastre-Merlín, A., and Jeppesen, E. 2014. Hydrological and water quality impact assessment of a Mediterranean limno-reservoir under climate change and land use management scenarios. Journal of Hydrology, 509:35466.

3. Wang, R., Kalin, L., Kuang, W., and Tian, H. 2014. Individual and combined effects of land use/cover and climate change on WolfBay watershed streamflow in southern Alabama. Hydrological Process, 28(22):5530-46.

4. Zhang, L., Nan, Z., Yu, W., and Ge, Y. 2016. Hydrological Responses to Land-use change scenarios under constant and changed climatic conditions. Environmental Management, $57: 412-431$.

5. Kabat, P., Claussen, M., Dirmeyer, P. A., Gash, J. H. C., Guenni, L.B., Meybeck, M., Pielke, R.A., Vörösmarty, Ch.I., Hutjes, R.W.A., and Sabine Lütkemeier (eds). 2004. Vegetation, Water, Humans and the climate. A new perspective on an Interactive system. Global Change. The IGBP series. Springer-Verlag Berlin Heidclberg Gmbl.

6. Hibbard, K.A., Hoffman, F. M., Huntzinger, D., and West, T.O. 2017. Changes in land cover and terrestrial biogeochemistry. In: Climate Science Special Report: Fourth National Climate Assessment, Volume I [Wuebbles, D.J., D.W. Fahey, K.A. Hibbard, D.J. Dokken, B.C. Stewart, and T.K. Maycock (eds.)]. U.S. Global Change Research Program, Washington, DC, USA, 277-302, doi: 10.7930/J0416V6X.

7. Vitousek, P. M., Mooney, H. A., Lubchenko, J., Melillo, J. M. 1997. Human domination of earth's ecosystems. Science, 277(5325):494-499.

8. Yang, X., Ren, L., Liu, Y., Jiao, D., and Jiang, Sh. 2014. Hydrological response to land use and land cover changes in a sub-watershed of West Liaohe River Basin, China. Journal of Arid Land, 6(6):678-689. 
9. Duveiller, G., Caporaso, L., Abad-Vinas, R., Perugini, L., Grassi, G., Arneth, A., Cescatti, A. 2020. Local biophysical effects of land use and land cover change: towards an assessment tool for policy makers. Land use policy, 91:104382.

10. Feddema, J. J., Oleson, K. W., Bonan, G. B., Mearns, L. O., Buja, L. E., Meehl, G. A., and Washington, W. M. 2005. The importance of land-cover change in simulating future climates. Science, 310:1674-1678.

11. Chen, J., and Li, X. 2004. Simulation of hydrological response to land-cover changes. China Journal of Applied Ecology, 15:833-836.

12. Zhang, T., Zhang, X., Xia, D., and Liu, Y. 2014. An Analysis of Land Use Change Dynamics and Its Impacts on Hydrological Processes in the Jialing River Basin. Water, 6:3758-3782.

13. Niraula, R., Meixner, T., and Norman, L. M. 2015. Determining the importance of model calibration for forecasting absolute/relative changes in streamflow from LULC and climate change. Journal of Hydrology, 522:439-451.

14. Brath, A., Montanari, A., and Moretti, G. 2006. Assessing the effect on flood frequency of land use change via hydrological simulation (with uncertainty). Journal of Hydrology, 32491-40:141-153.

15. Guo, H., Qi, H., and Jiang, T. 2008. Annual and seasonal streamflow responses to climate and land-cover changes in the Poyang Lake basin, Journal of Hydrology, 355:106-122.

16. Li, Z., Liu, W-Z., Zhang, X-c., and Zheng, F-I. 2009. Impacts of land use change and climate variability on hydrology in an agricultural catchment on the Loess Plateau of China. Journal of Hydrology, 377(1):35-42.

17. Zhang, L., Nan, Z., Yu, W., and Ge, Y. 2015. Modeling Land-Use and Land-Cover Change and Hydrological Responses under Consistent Climate Change Scenarios in the Heihe River Basin, China. Water Resource Management, 29(13): 4701-4717.

18. Luo, K., Tao, F., Moiwo, J. P., and Xiao, D. 2016. Attribution of hydrological change in Heihe River Basin to climate and land use change in the past three decades. Scientific Reports, $6: 33704$.

19. Shrestha, S., and Htut, A.Y. 2016. Land use and climate change impacts on the hydrology of the Bago River Basin, Myanmar. Environmental Modeling Assessment, 21:819-833. 
20. Ma, X., Xu, J., and Noordwijk, M. V. 2010 Sensitivity of streamflow from a Himalayan catchment to plausible changes in land cover and climate. Hydrological Processes, 24:1379-1390.

21. Paul, M., Mohammad, A., and Ahiablame, L. 2016 Spatial and Temporal Evaluation of Hydrological Response to Climate and Land use change in three South Dakota Watersheds. Journal of the American Water Resources Association, 1-20.

22. Yang, L., Feng, Q., Yin, Z., Wen, X., Si, J., Li, C., and Deo, R.C. 2017. Identifying separate impacts of climate and land use/cover change on hydrological processes in upper stream of Heihe River, Northwest China. Hydrological Processes, 31:1100-1112.

23. Soytong P, Janchidfa K, Phengphit N, Perera, Chayhard S., and Ranjith. 2016. The Effects of Land Use Change and Climate Change on Water Resources in the Eastern Region of Thailand. 12: 1695-1722.

24. Dwarakish, G. S., and Ganasri, B. P. 2015. Impact of land use change on hydrological systems: A review of current modeling approaches. Cogent Geoscience, 1:1-18.

25. Chawla, I., and Mujumdar, P. P. 2015. Isolating the impacts of land use and climate change on streamflow, Hydrology and Earth System Sciences, 19:3633-3651.

26. Legesse, D., Abiye, T. A., Vallet-Coulomb, C., and Abate, H. 2010. Streamflow sensitivity to climate and land cover changes: Meki River, Ethiopia. Hydrology and Earth System Sciences, 14:2277-2287.

27. Fan, M., and Shibata, H. 2015. Simulation of watershed hydrology and stream water quality under land use and climate change scenarios in Teshio River watershed, northern Japan. Ecological Indicator, 50:79-89.

28. Krysanova, V., and White, M. 2015. Advances in water resources assessment with SWAT-an overview. Hydrological Sciences Journal, 60(5):771-783.

29. Wang, W., Shao, Q., Yang, T., Peng, S., Xing, W., Sun, F., et al. 2013. Quantitative assessment of the impact of climate variability and human activities on runoff changes: a case study in four catchments of the Haihe River basin, China. Hydrological Process, 27(8):1158-74.

30. Sang, Y-F., Wang, Z., Liu, C., and Yu, J. 2014. The impact of changing environments on the runoff regimes of the arid Heihe River basin, China. Theoretical Applied Climatology, 115(1- 2):187-195. 
31. Wanger, P., Kumar, S., and Schneider, K. 2013. An assessment of land use change impacts on the water resources of the Mula and Mutha Rivers catchment upstream of Pune, India. Hydrological Earth System Science, 17:2233-2246.

32. Wijesekara, G.N., Gupta, A., Valeo, C., Hasbani, J.G., Qiao, Y., Delaney, P., \& Marceau, D.J. 2012. Assessing the impact of future land-use changes on hydrological processes in the Elbow River watershed in southern Alberta, Canada. Journal of Hydrology, 412-413:220232.

33. Baker, T. J., and Miller, S. N. 2013. Using the Soil and Water Analysis Tools (SWAT) to assess land use impact on water resources in an East Africa watershed. Journal of Hydrology, 486:100-111.

34. Yin, J., He, F., Xiong, Y., and Qiu, Y. G. 2017. Effect of land use/land cover and climate changes on surface runoff in a semi-humid and semi-arid transition zone in Northwest China. Hydrology and Earth System Science, 21:183-196.

35. Zhou, F., Xu, Y., Chen, Y., Xu, C. Y., Gao, Y., and Du, J. 2013. Hydrological response to urbanization at different spatiotemporal scales simulated by coupling of CLUE-S and the SWAT model in the Yangtze River Delta region. Journal of Hydrology, 485:113- 125.

36. Hsu, K., Gupta, H. V., Gao, X., and Sorooshian, S. 1999. Estimation of physical variables from multichannel remotely sensed imagery using a neural network: Application to rainfall estimation. Water Resources Research, 35(5):1605-1618.

37. Drusch, M., and Wood, E. F. 2001. Vegetative and Atmospheric Corrections for the Soil Moisture Retrieval from Passive Microwave Remote Sensing Data: Results from the Southern Great Plains Hydrology Experiment 1997. Journal of Hydrometeorology, 2(2): 181-192.

38. Liang, S. 2007. Recent developments in estimating land surface biogeophysical variables from optical remote sensing. Progress in Physical Geography, 31(5): 501-516.

39. Kabite, G., Muleta, M.K., Gessesse, B., and Koriche, S.A. 2019. Spatiotemporal climate and vegetation greenness changes and their nexus for Dhidhessa River Basin, Ethiopia. Environmental System Research, 8:31.

40. Kabite, G., Muleta, M. K., and Gessesse, B. 2020. Spatiotemporal land cover dynamics and drivers for Dhidhessa River Basin (DRB), Ethiopia. Modelling Earth System and Environment, 6:1089-1103. 
41. Yohannes, O.2008. Water Resources and Inter-Riparian Relations in the Nile Basin: The Search for an integrative Discourse. 270.

42. Oromia Water Works Design and Supervision Enterprise (OWWDSE). 2014. Dhidhessa SubBasin Soil Survey Report. Dhidhessa-Dabus Integrated Land Use Planning Study Project. Unpublished.

43. Geological Survey of Ethiopia (GSE). 2000. Geology of the Nekemte and Gimbi Area. Sheet Number: NC-37-9 and NC-36-12, respectively. Unpublished.

44. Sharp, R., Tallis, H.T., Ricketts, T., Guerry, A.D., Wood, S.A., Chaplin-Kramer, R., Nelson, E. E, D., Wolny, S., Olwero, N., Vigerstol, K., Pennington, D., Mendoza, G., Aukema, J., Foster, J., Forrest, J. C, D., Arkema, K., Lonsdorf, E., Kennedy, C., Verutes, G., Kim, C.K., Guannel, G., Papenfus, M., Toft, J., Marsik M, Bernhardt, J., Griffin, R., Glowinski, K., Chaumont, N., Perelman, A., Lacayo, M. Mandle, L., Hamel, P., V Vogl AL, Rogers, L., Bierbower, W., Denu, D., and Douglass J. 2018. InVEST 3.5.0 User's Guide. The Natural Capital Project, Stanford University, University of Minnesota, The Nature Conservancy, and World Wildlife Fund: Stanford.

45. Neitsch, s. 1., Arnold, J. G., Kiniry, J.R., and Williams, J. R. 2011. Soil and Water Assessment Tool theoretical documentation: version 2009: Texas Water Resources Institute, 1-24.

46. Griensven, A. V., Ndomba, P., Yalew, S., and Kilonzo, F. 2012. Critical review of SWAT applications in the upper Nile basin countries. Hydrology and Earth System Sciences, 16:3371-3381.

47. Gassman, P. W., Sadeghi, A. M., Srinivasan, R. 2014. Applications of the SWAT Model Special Section: Overview and Insights. Journal of Environmental Quality, 43:1-8.

48. Shawul, A.A., Chakma, S., and Melese, A.M. 2019. The response of water balance components to land cover change based on hydrologic modeling and partial least squares regression (PLS) analysis in the Upper Awash Basin. Journal of Hydrology: Regional Studies, 26(2019)100640.

49. Nejadhashemi, A., Wardynski, B., and Munoz, J. 2011. Evaluating the impacts of land use changes on hydrological responses in the agricultural regions of Michigan and Wisconsin. Hydrology and Earth System Sciences Discussions, 8(2):3421-68.

50. Haigen, Z., Shengtian, Y., Zhiwei, W., Xu, Z., Ya, L., and Linna, W. 2015. Evaluating the suitability of TRMM satellite rainfall data for hydrological simulation using a distributed 
hydrological model in the Weihe River catchment in China. Journal of Geographical Science, 25(2):177-195.

51. Akbari, S., and Singh, R. 2012. Hydrological modeling of catchments using MIKE SHE. IEEEInternational Conference on Advances in Engineering, Science and Management, 335340.

52. Elfert, S., and Bormann, H. 2010. Simulated impact of past and possible future land use changes on the hydrological response of the Northern German lowland 'Hunte' catchment. Journal of Hydrology, 383:245-255.

53. Zhou, J., Liu, Y., Guo, H., and He, D., 2014. Combining the SWAT model with sequential uncertainty fitting algorithm for streamflow prediction and uncertainty analysis for the Lake Dianchi Basin, China. Hydrol. Processes, 28:521-533.

54. Abbaspour, K.C., Yang, J., Maximov, I., Siber, R., Bogner, K., Mieleitner, J., Zobrist, J. and Srinivasan, R. 2007. Modelling hydrology and water quality in the pre-alpine/alpine watershed using SWAT. Journal of Hydrology, 333:413-430.

55. Wu, H., and Chen, B., 2015. Evaluating uncertainty estimates in distributed hydrological modeling for the Wenjing River watershed in China by GLUE, SUFI-2, and ParaSol methods. Ecol. Eng., 76:110-121.

56. Roth, V., Lemann, T., Zeleke, G., Subhatu, A.T., Nigussie, T.K., and Hurni, H. 2018. Effects of climate change on water resources in the upper Blue Nile Basin of Ethiopia. Heliyon, 4(2018) e00771.

57. Lemann, T., Roth, V., Zeleke, G., Subhatu, A., Kassawmar, T., and Hurni, H. 2019. Spatial and Temporal Variability in Hydrological Responses of the Upper Blue Nile basin, Ethiopia. Water, 11:21.

58. Arnold, J.G., Moriasi,D.N., Gassman, P.W., K.C. Abbaspour, M.J. White, R. Srinivasan, C. Santhi, R.D. Harmel, A. Van Griensven, M.W. and Liew, V. 2012. SWAT: Model use, calibration, and validation, Trans. ASABE 55:1491-1508.

59. Conway, D. 2000. The Climate and Hydrology of the Upper Blue Nile River. The Geographical Journal, 1:49-62.

60. Tena, B. A., Srinivasa Rao, G. V. R., and Yerramsetty, A. 2015. Assessment of Spatio Temporal Occurrence of Water Resources in Didessa Sub-Basin, West Ethiopia. 
International Journal of Civil, Structural, Environmental and Infrastructure Engineering Research and Development (IJCSEIERD), 5(1):105-120.

61. Kabite, G., and Gessesse, B. 2018. Hydro-geomorphological characterization Dhidhessa River Basin, Ethiopia. International Soil and Water Conservation Research, 6:175-183.

62. Moriasi D N, Arnold J G, Van Liew M W et al., 2007. Model evaluation guidelines for systematic quantification of accuracy in watershed simulations. Transactions of the American Society of Agricultural and Biological Engineers, 50(3): 885-900.

63. Worku, T., Khare, D., Tripathi, S.K., 2017. Modeling runoff-sediment response to land use/ land cover changes using integrated GIS and SWAT model in the Beressa watershed. Environ. Earth Sci. 76 (16):1-14.

64. Gashaw, T., Tulu, T., Argaw, M., Worqlul, A.W., 2018. Modeling the hydrological impacts of land use/land cover changes in the Andassa watershed, Blue Nile Basin, Ethiopia. Science of Total Environment, 619-620:1394-1408.

65. Teklay, A., Dile, Y.T., Setegn, S.G., Demissie, S.S., Asfaw, D.H., 2018. Evaluation of static and dynamic land use data for watershed hydrologic process simulation: a case study in Gummara watershed, Ethiopia. Catena 172:65-75.

66. Mango, L.M., Melesse, A.M., McClain, M.E., Gann, D., and Setegn, S.G. 2011. Land use and climate change impacts on the hydrology of the upper Mara River Basin, Kenya: results of a modelling study to support better resource management. Hydrology and Earth System Sciences, 15:2245-2258.

67. Niu, X. Y., Yan-Hua, W., Hao, Y., Jia-Wen, Z., Jun, Z., Mei-Na, X., and Biao, X. 2015. Effect of land use on soil erosion and nutrients in Dianchi Lake Watershed, China. Pedosphere, 25:103-111.

68. Liu, Y. 2016. Landscape connectivity in Soil Erosion Research: concepts, implication, quantification. Geographical Research, 1:195-202.

69. Brook, H., Argaw, M., Sulaiman, H. \& Abiye, T. A. 2011 The Impact of Land Use/Land Cover Change on Hydrological Components due to Resettlement Activities: SWAT Model Approach. International Journal of Ecology and Environmental Sciences, 37(1):49-60.

70. Chimdessa, K., Quraishi, S., Kebede, A., and Alamirew, T. 2019. Effect of land use land cover change on river flow and soil loss in Didessa River Basin, South West Blue Nile, Ethiopia. Hydrology, 6(1): 2. 
71. Berihun, M. L., Tsunekawa, A., Haregeweyn, N., Meshesha, D.T., Adgo, E., Tsubo, M., Masunaga, T., Fenta, A.A., Sultan, D., Yibeltal, M., and Ebabu, K. 2019. Hydrological responses to land use/land cover change and climate variability in contrasting agroecological environments of the Upper Blue Nile basin, Ethiopia. Science of the Total Environment, 689: 347-365.

72. Chen, Q., Chen, H., Wang, J., Zhao, Y., Chen, J., and Xu, C. 2019. Impacts of climate change and land use change on hydrological extremes in the Jinsha River Basin. Water, 11:1398.

73. Belete, M., Deng, J., Abubakar, G. A., Tesgome, M., Wang, K., Woldethadik, M., Zhu, E., Comber, A., and Gudo, A. Partitioning the impacts of land use/land cover change and climate variability on water supply over the source region of Blue Nile Basin. Land Degradation and Development, https:doi.org/10.1002/ldr.3589. Accepted article.

74. Tamm, O., Maasikamae, S., Padari, A., and Tamm, T. 2018. Modelling the effects of land use and climate change on the water resources in the eastern Basaltic Sea region using the SWAT model. Catena, 167:78-89.

75. Li, G., Zhang, F., Jing, Y., Liu, Y., Sun, G., 2017. Response of evapotranspiration to changes in land use and land cover and climate in China during 2001-2013. Sci. Total Environ. 596-597:256-265.

76. Mekonnen, D.F., Duan, Z., Rientjes, T., Disse, M., 2018. Analysis of combined and isolated effects of land-use and land-cover changes and climate change on the upper Blue Nile River basin's streamflow. Hydrol. Earth Syst. Sci., 22 (12):6187-6207.

77. Welde, K., Gebremariam, B. 2017. Effect of land use land cover dynamics on hydrological response of watershed: Case study of Tekeze Dam watershed, northern Ethiopia. International Soil and Water Conservation Research, 5:1-16. 